University of California, Hastings College of the Law UC Hastings Scholarship Repository

Faculty Scholarship

$1-1-2013$

\title{
Just a 'Bubble'? Perspectives on the Enforcement of International Criminal Law by National Courts
}

Naomi Roht-Arriaza

UC Hastings College of the Law, rohtarri@uchastings.edu

Follow this and additional works at: https://repository.uchastings.edu/faculty_scholarship

\section{Recommended Citation}

Naomi Roht-Arriaza, Just a 'Bubble'? Perspectives on the Enforcement of International Criminal Law by National Courts, 11 J. Int'l Crim. Just. 537 (2013).

Available at: https://repository.uchastings.edu/faculty_scholarship/1301

This Article is brought to you for free and open access by UC Hastings Scholarship Repository. It has been accepted for inclusion in Faculty Scholarship by an authorized administrator of UC Hastings Scholarship Repository. For more information, please contact wangangela@uchastings.edu. 


\title{
Just a 'Bubble’?
}

\section{Perspectives on the Enforcement of International Criminal Law by National Courts}

\author{
Naomi Roht-Arriaza*
}

\begin{abstract}
The international criminal justice project is not in decline. Its focus, however, has shifted to where it, arguably, belongs: to national courts. National courts are integral to both the origins and the future of international criminal justice. The difficulties involved in national prosecutions led to the establishment of international courts and the rise of universal jurisdiction; the difficulties in using these latter forums, in turn, is leading back to national courts. This article examines the forward movement and the backlash of the enforcement of international criminal law by national courts, drawing in particular on the Latin American and the Spanish examples. It concludes by arguing that the hangover after the euphoria should be used to correct the sky-high expectations and to (re)determine the relationship between international and national and among different national jurisdictions.
\end{abstract}

\section{Introduction}

As I sit down to write about the decline of international criminal justice, a national court in Guatemala has set a date for the trial of former dictator Efrain Ríos Montt and his former head of military intelligence, accused in the massacre of over 1700 Ixil Mayans from 1982 to 1983. For the first time, a former head of state in the Americas has been held over for trial on charges of genocide and crimes against humanity. It has taken 12 years to get here.

Perhaps this is a metaphor. The problem is not so much that the international criminal justice project is in decline, as it is that the focus has shifted back to where, arguably, it belongs: to national trials in the courts of the state where the crimes occurred. Often, despite the universal lip service paid to so-called 'positive' complementarity, in terms of resources and attention national prosecutions for international crimes have been seen as somehow peripheral to the international justice project, but they are integral to both its origins and its future. It was, in part, recognition of the difficulties involved in

* Professor of Law, University of California, Hastings College of the Law. [rohtarri@ uchastings.edu] 
national criminal prosecutions that led the turn to using foreign and international courts; it is the difficulties in using these latter fora, and the overselling of their potential, that is leading the cases, in turn, back to national courts. That is, I think, as it should be.

But that does not mean it's easy.

\section{National Courts and International Crimes}

National courts continue to grapple with whether to prosecute serious crimes from the past in light of difficulties with amnesties, statutes of limitations and concerns about retroactivity and potential violations of the principle of legality. On balance, the overall trend is towards prosecutions, but it is by no means unidirectional. National prosecutions have moved forward in Latin America, albeit unevenly and with difficulty, even where amnesty laws once prevailed. The statistics are impressive: in Argentina, as of 2012, 1943 people have been held for trial in cases arising from the 'dirty war' of the 1970s. Many of the accused are now being tried in what are termed as 'mega-trials' involving dozens of defendants and hundreds of victims and witnesses. In Chile, 800 state agents have been held for trial in 1342 cases for killing, forced disappearance or (in a few cases only) torture during the Pinochet dictatorship. To date, 250 have been convicted. ${ }^{1}$ In Peru, former President Fujimori was convicted of both human rights and corruption related crimes, and several top army officers are also in jail, although a larger number have been acquitted of human rights related crimes. Investigations and prosecutions for international crimes are underway as well in Uruguay, Colombia and Ecuador. In Brazil, prosecutors are investigating forced disappearances as 'kidnappings' not subject to an amnesty law.

In a few countries, including Peru, Argentina and Uruguay, amnesties have been formally annulled, while in others like Chile the laws, while still in place, have been interpreted to exclude international crimes. In most countries in the region, international crimes have only recently (if at all) been incorporated into the penal code, and so most prosecutions are for common crimes like murder and kidnapping. However, courts have found that these crimes in the context of 1970s and 1980s repression also constitute, at least since Nuremberg, crimes against humanity, which are prohibited as a matter of customary law. As such, they are not subject to statutes of limitation or other impediments to prosecution, and may thus be tried without violating principles of legality.

The Inter-American Commission and Court have played a key role in insisting that the rights of the victims require that such crimes be investigated

1 Centro de Estudios Legales y Sociales, 'Estadísticas de los juicios por crímenes de lesa humanidad en Argentina', October 2012, available online at www.cels.org.ar/blogs; ICSO, 'Latest Human Rights Case Statistics for Chile', available online at www.icso.cl/observatorio-derechoshumanos/cifras-causas-case-statistics (all websites visited 29 April 2013). 
and, where warranted, prosecuted, starting with the 2001 Barrios Altos case, followed by similar rulings in cases involving Chile, Brazil, Uruguay and, most recently, El Salvador. Even where there have been few inroads into the amnesty law, for example in Brazil and El Salvador, the Inter-American Court's rulings have created pressure on judges and the executive branch. Transnational prosecutions, discussed below, have added to that pressure, as has the existence of persistent and creative groups of victims, family members and human rights advocates.

Of course, forward movement has created backlash, as it does in all these cases. In Chile, those most closely connected to forced disappearances will spend their lives in prison, but many others have been convicted and then released with little or no jail time as a result of reductions in sentence based on the passage of time. In Peru, mid-ranking officers have been acquitted when judges refuse to apply the theories of indirect liability pioneered in the Fujimori trial, and insist on evidence of direct participation in crimes. In Guatemala, defendants have managed endless delays, and have invited the country's Constitutional Court to annul the provisions of the 1996 amnesty law that exempt genocide, disappearances and other international crimes from its application. And in Brazil, the Supreme Court held in 2010 that torture and killings by the military are still covered by an amnesty law. Still, the overall regional balance tilts against impunity for these crimes.

Elsewhere, some of the difficulties involved in meshing national and international prosecutions can be seen in the decision by Uganda's Constitutional Court to uphold the application of the 2000 amnesty law despite changes in the law and arguments that blanket amnesties for the Lord's Resistance Army (LRA) would violate Uganda's treaty obligations. The first case to come before the newly-constituted International Crimes Division, that of LRA commander Thomas Kwoyelo, resulted in a finding that amnesty must apply under principles of equal protection, since other LRA members had been granted amnesty and the government never provided for the specific exemptions required under the law. ${ }^{2}$ More than an endorsement of amnesties, perhaps, the case may be read to stand for the problems involved in changing horses mid-stream.

In another example of a counter-current, Spain's highest court also rejected arguments that international crimes have to be prosecuted despite legal impediments. In a case involving the removal of Investigating Magistrate Baltasar Garzón from his position, the Supreme Court held that Garzón's investigations into the fate of those whose bodies were never found in the wake of the Spanish Civil War (1936-1939) were unwarranted. ${ }^{3}$ Garzón, following the reasoning of the Argentine and other Latin American courts as well as

2 Thomas Kwoyelo alias Latoni v. Uganda [2011], UGCC 10, 21 September 2011, available online at www.ulii.org/ug/judgment/2011/10 (visited 29 April 2013).

3 For a more detailed explanation of the case, see my ASIL Insight entry, published 25 July 2012 , available online at www.asil.org/pdfs/insights/insight120725.pdf, from which some of this section is excerpted. 
previous decisions of Spanish courts in cases involving Argentina and Chile, initially ruled that he had jurisdiction because these were international crimes, and so not subject to either amnesty or a statute of limitations. Eventually, after finding that no potential defendants were still alive, he sent the case to local courts to determine where the bodies were buried.

Garzón's act provoked a complaint to the courts that he had committed the crime of prevaricación, which requires that the judge knowingly and deliberately act against settled law. On 27 February 2012, the Supreme Court found him innocent of that charge. But the Court went on to discuss why Garzón's initial rulings, even though not criminal, had been incorrect. It found that, first, Garzón could not use Spanish criminal proceedings when the purpose of the investigation was to look into historical truth rather than focusing narrowly on a criminal defendant. Second, it declared that the case could not be brought under the principle of legality (the prohibition on ex post facto law). Garzón had found that the civil war era crimes constituted a continuing crime of illegal detention, which given the circumstances was at the same time a domestic crime, and a crime against humanity under customary international law. As noted above, this dual nature of acts that are simultaneously national and international crimes has been widely used in Latin American courts to allow prosecution of crimes that were not defined as international crimes in the penal codes of the time. The Court rejected the continuing crimes argument, and found that because no international law exception could apply, the crimes were subject to the statute of limitations of national penal law, which had long since expired. With respect to Spain's 1977 Amnesty Law, the Court found that, even if the amnesty law would now be considered a violation of international law, that determination is not retroactive.

Like the Ugandan Constitutional Court, and like the Brazilian Supreme Court in 2010, the Spanish Court in essence found that the decisions made long ago, before the consolidation of anti-impunity norms, had to override those current norms; all three courts grounded their decisions in the principles of legality and non-retroactivity of the penal law. Whatever one may think of the reasoning, eventually the codification of international crimes in national law, and of their inamnestiable and imprescriptable characteristics, should make arguments about retroactivity less and less salient. And given the countervailing jurisprudence from other courts, especially in Latin America, the overall balance is probably slightly favourable to advocates of prosecutions.

\section{Universal Jurisdiction}

One area where pruning back has definitely occurred is in the acceptance and use of universal jurisdiction to prosecute international crimes in third party courts. But it is heavy pruning, not complete amputation. The pruning has taken the form of requiring much closer links between the 
alleged crimes and the forum state, and of making the use of these courts secondary to the International Criminal Court (ICC). Thus, in Spain, as in Belgium before it, pressure from the United States, Israel and China about ongoing, and embarrassing, investigations into top officials led to a 2009 modification of Article 23.4 of the Organic Law, which in the wake of the Pinochet case had grounded a large number of requests to the Spanish courts to intervene. The modification limits Spanish jurisdiction to those cases where the alleged perpetrator is present in Spain, where the victims or perpetrator is of Spanish nationality, or where there is some other relevant tie to Spain. In addition, the case cannot be the subject of an effective investigation or prosecution in another national court or in an international tribunal. It also, on the plus side, adds crimes against humanity and human trafficking to the list of universal jurisdiction crimes. ${ }^{4}$ As a result of these modifications and their chilling effect on both judges and complainants, a number of investigations, including those involving Tibet, and the United States have been shelved. For example, on 20 December 2012, the Spanish Supreme Court denied an appeal of the dismissal of a case against Bush-era officials for creating the legal context for torture in Guantánamo, on grounds that the United States government's administrative and disciplinary proceedings were adequate.

However, not all Spanish universal jurisdiction cases have disappeared in the wake of changes to the law. A case against high-ranking military and police officers for genocide, terrorism and torture in Guatemala remains open, and evidence in the case has been shared with the Guatemalan prosecutors' office. While there are a few victims of Spanish nationality involved, most victims (and all alleged perpetrators) are Guatemalan. The case involving the killing of six Jesuit priests, their housekeeper and her daughter in El Salvador also continues. While six of the eight victims were Spanish nationals, the impact of the case is primarily felt in El Salvador, where it is one of several emblematic crimes of the civil war period. So far, the Salvadoran Supreme Court has denied extradition requests by Spain. In an ironic twist, one of the defendants in the case, former Colonel Inocente Montano, has been detained in the United States and pled guilty to visa fraud charges stemming from his non-disclosure of his military service and role in the case when he moved to the United States many years ago. The Spanish government has submitted a request for extradition, once Montano finishes serving his time in a United States prison. If the United States accedes, he may be the first Salvadoran defendant tried in the case.

A final irony: the one place where an investigation continues into Franco-era crimes (the investigation shut down by the Spanish courts in the Garzón case) is Argentina. Judge Maria Servini de Cubria opened an investigation on 14 April 2010 in a Buenos Aires federal court into these crimes under Argentina's own universal jurisdiction law. One of the victims, 93 year old Dario Rivas, for example, asked the court to investigate the

4 The modification to Art. 23.4 can be found in Organic Law 1/09, 3 November 2009. 
1936 murder of his father, a former Republican mayor of the small town of Castro del Rey whose body has still not been found. As of December 2012, some 5000 people had joined the complaint, and the judge was exploring how to take testimonies by video conference. While Garzón has now been effectively removed from the Spanish judiciary, ${ }^{5}$ his revenge may be that the target of his first universal jurisdiction case - crimes in Argentina - will return the favour by looking into the hundreds of thousands of missing in his homeland.

The setbacks to a truly universal jurisdiction are real: it seems that states are willing to countenance a 'no safe haven' policy for alleged criminals who reside on or visit their territory, but not to pursue them beyond borders. This is less than what many advocates hoped for in 1998, and creates problems in amassing the necessary evidence in time to snare visiting génocidaires or war criminals. But it is not the 'death' of universal jurisdiction, by any means. Indeed, over the last year, a South African court told the prosecutors' office that it was required to open an investigation into the crimes of Zimbabwean police and government officials accused of systematic torture, arising especially out of a March 2007 incident. Lawyers for the victims argued that under South Africa's ICC Act the state was obliged to investigate when there was evidence that the alleged perpetrators regularly visited South Africa, and so prosecutors could anticipate their presence. $^{6}$ Hissène Habré, the former dictator of Chad, is finally on trial in Senegal, where he resides, after a decade long saga that has encompassed the Senegalese and Belgian courts, an African Union commitment to an 'African' trial, changes in Senegalese law, a decision by the International Court of Justice directing Senegal to properly investigate and try the case, and a novel funding scheme wherein the European Union finances part of a trial in Senegal. ${ }^{7}$ Rwandans are on trial in Sweden (for genocide) ${ }^{8}$ and Canada (for genocide and crimes against humanity). ${ }^{9}$ The United Kingdom recently arrested Colonel Kumar Lama, accused of torturing two men when he was a police official in Nepal in 2005, while he was in the country visiting family. So, like much of international justice, we may be witnessing a tamping down of expectations. Universal jurisdiction will be a useful adjunct when alleged perpetrators are found residing or travelling outside the country where the crimes took place, but it will not replace (or, for the most part, catalyse) domestic investigations.

5 He was convicted of illegal wiretapping in January 2012, in a case involving allegations of corruption that reached high into the ruling Popular Party. See my ASIL Insight, supra note 3.

6 South African Litigation Centre and another v. National Director for Public Prosecutions and another, North Gauteng High Court, Pretoria, 8 May 2012. See the contribution by Gerhard Werle and Paul Bornkamm on the case in this issue of the Journal.

7 For a chronology and detailed discussion, see www.hrw.org/habre-case (visited 29 April 2013).

8 See www.publicserviceeurope.com/article/2852/swedens-unprecedented-and-unique-genocide -trial (visited 29 April 2013).

9 See www.ccij.ca/programs/cases/index.php?DOCINST=19 (visited 19 April 2013). 


\section{Conclusion}

In the end, there is unmistakably a hangover after the euphoria of 1998. The question is, was the experiment of international justice a 'bubble', like our housing and financial bubbles, now sadly burst? Or is the current period a necessary corrective to sky-high expectations, combined with an inevitable backlash from still powerful actors? I would suggest that the latter is a more fruitful optic, and that the moment creates an opportunity for creative broadening of justice mechanisms. In the short term, this will mean figuring out how to use the idea of positive complementarity to innovate in how international actors, starting with the ICC, engage with national systems. This engagement may at times look more like the United Nation's involvement in the Commission Against Impunity in Guatemala, which embedded international prosecutors with national ones to train and report on but not actually prosecute, than the current ICC support for national prosecutions. At other times, building on the experience with Habré, it may involve creating regional institutions like the proposed Criminal Chamber of the African Court of Justice and Human Rights, which will need both resources and independence to become more than a transparent effort to undermine the ICC. And in the longer term, these institutions, whatever their national-international conformation, will have to develop greater capacity than they have shown to date to confront the financiers, plunderers, arms merchants and money launderers who fuel conflicts, and who rob peoples of the fruits of peace. 